research. Because the labeling technique was still immature, however, conclusions regarding the significance of the different conformations are difficult to make

Here, we describe the preparation of fully active $\alpha$-actin obtained from a baculovirus expression system for single FRET measurement. We developed $\alpha$-actin recombinants, of which two domains of the tetramers have specific sites for fluorescent probes. This specific labeling technique offers to significantly expand the information acquired from actin studies.

\section{$1 \mathrm{P202}$ セミインタクト細胞とそのリシール技術を用いたメンブレンダ $1 \mathrm{C1240}$ イナミクス研究}

Establishment of semi-intact cell system and application of its resealing technique: a study of membrane dynamics

Fumi Kano ${ }^{1,2}$, Tamaki Arai ${ }^{1}$, Mariko Matsuto ${ }^{1}$, Masayuki Murata ${ }^{1},\left({ }^{1}\right.$ Graduate School of Arts and Sciences, The University of Tokyo: ${ }^{2}$ PRESTO, JST

Semi-intact cells are cells, whose plasma membranes are permeabilized with detergent or toxins, and are called as "cell-type test tube". We use streptolysin $\mathrm{O}$ (SLO) to permeabilize the cell. SLO-mediated pores are about $30 \mathrm{~nm}$ in diameter, which allows the entry of proteins, probes, and small chemical compounds, etc. into cells. By adding the cytosol, which is prepared from the cells under conditions different in cell cycle, differentiation stage, or disease state, we can change the intracellular environment and reconstitute the various physiological phenomena, keeping their experimental conditions synchronized, in semi-intact cells. So far we established the several assays for cell cycle-dependent changes of organelle morphology and membrane traffic by coupling semi-intact cell system with GFP visualization technique, and elucidated its regulatory mechanisms. Recently, it is found that the SLO-mediated pores can be resealed by calcium ion. We confirmed that the resealed cells restored the endocytosis and exocytosis driven by external stimulus, which are difficult to reconstitute in semi-intact cells due to the permeabilization of plasma membrane, and some cells gained the ability to proliferate. In addition, the resealing technique provided us the way to investigate the mechanisms of signal transduction pathways, or the one that takes time such as epigenetic alternation. In this paper, we will show our reconstitution systems of organelle dynamics and membrane traffic using semi-intact or resealed cells.

\section{$1 \mathrm{P203}$ ラマンスペクトルで見る酵母と動物細胞のミトコンドリア} Raman spectroscopy of yeast and animal cell mitochondria Minoru Kakita, Hiro-o Hamaguchi, (The University of Tokyo)

Mitochondrion has a very important role for cell activity because of its ability to make energy in the form of ATP. Various methods for mitochondrial isolation have been established to study its mechanism. With the progress in genetic engineering, new methods to study mitochondria in living cell have also been developed. However, isolation methods may suffer from unknown contamination and genetic analysis is restricted only to specific known species. Raman spectra can be obtained from living cell as well as from isolated mitochondria and contain rich molecular information. In this report, yeast and animal mitochondria are studied using Raman spectroscopy, instead of conventional genetic methods or assays. Isolated and in vivo mitochondria are compared to study the effect of extraction/isolation. Centrifugal separation (which is the most widely used method of mitochondria separation) is used for isolating mitochondria from cells at each stage of the growth curves.

\section{$1 P 204$ 細菌べん毛蛋白質輸送における FliI ATPase と FliT シャペロ ンとの相互作用}

Interaction between FliI ATPase and a substrate-specific chaperone FliT during bacterial flagellar protein export

Tohru Minamino ${ }^{1,2}$, Miki Kinoshita ${ }^{1}$, Katsumi Imada ${ }^{1}$, Keiichi Namba ${ }^{1},\left({ }^{1}\right.$ Graduate School of Frontier Biosciences, Osaka University: ${ }^{2}$ PRESTO, JST)

The bacterial flagellum, which is responsible for motility, is a biological nanomachine consisting of a rotary motor, a universal joint and a helical screw. For construction of the flagellum, most of the flagellar proteins are translocated into the central channel of the growing structure by the flagellar protein export apparatus. The proton motive force across the cytoplasmic membrane is utilized as an energy source for protein export.

FliI ATPase forms a complex with its regulator $\mathrm{FliH}$ in the cytoplasm. The FliH-FliI complex delivers export substrates along with FliJ into the export gate made of integral membrane components of the export apparatus and facilitates the initial entry of the substrates into the narrow pore of the gate.

FliT acts as a substrate-chaperone responsible for the filament-capping protein FliD. The FliT-FliD complex directly binds to FliI and FliJ. Our recent structural and functional analyses have revealed that the C-terminal segment of FliT controls its interaction with FliI and FliJ. However, it remains unknown how it does.

In this study, we analyzed the FliI-FliT interaction in more detail. We show that FliT binds to the extreme $\mathrm{N}$-terminal region of FliI with high affinity and to the C-terminal domain with low affinity. We also show that the C-terminal segment of FliT inhibits the interaction with the extreme $\mathrm{N}$-terminal region of FliI. Based on these results, we will discuss the regulatory mechanism of the FliI-FliT interaction during the export of FliD.

\section{$1 P 205$}

\section{酢酸菌 Gluconobacter oxydans におけるべん毛運動の誘導}

Induction of the flagellar motility in Gluconobacter oxydans, an acetic acid bacterium

Toshiharu Yakushi ${ }^{1}$, Shin-ya Kubota ${ }^{2}$, Masako Fujii ${ }^{1}$, Takeshi Hosaka ${ }^{2}$, Kikuo $\operatorname{Sen}^{2}$, Kazunobu Matsushita ${ }^{1},\left({ }^{1}\right.$ Yamaguchi University: ${ }^{2}$ Shinshu University $)$

Gluconobacter oxydans, a member of acetic acid bacteria, catalyzes oxidative fermentation such as acetic acid from ethanol and L-sorbose from D-sorbitol. Through such the oxidative fermentation, $G$. oxydans can produce energy as the form of proton motive force. Thus, we hypothesize that energy metabolism is crucial in the oxidative fermentation. Flagellar motility is a major locomotive mean of bacteria driven by the proton motive force. The G. oxydans $621 \mathrm{H}$ strain has a set of the flagellar genes and swims presumably by its flagella Here, we examined conditions where the flagellar motility is induced in $G$. oxydans.

Swimming fractions of, and production of flagellins in, G. oxydans were dependent on concentrations of carbon and energy sources, such as D-glucose, glycerol, and D-sorbitol. Their high concentrations induced the flagellar motility. It was prominent in the late exponential growth phase. Even under low concentrations of carbon and energy sources, the flagellar motility was induced by ethanol, a source of energy convertible to acetic acid. Furthermore, acetic acid itself induced the flagellar motility. These results suggest that the flagellar motility is induced under the conditions with enough energy and that actions of their metabolites are some cues for the induction in G. oxydans.

\section{P206 ペニバチルスのベん毛基部にあるらせん構造体の構造解析} A new spiral structure at the proximal end of Paenibacillus flagella

Kyohei Miyauchi ${ }^{1}$, Yoshika Nosaka ${ }^{2}$, Masatoshi Fujiwara ${ }^{3}$, Ryo Harasawa ${ }^{3}$, Shin-Ichi Aizawa ${ }^{1}$, ( ${ }^{1}$ Prefectural University of Hiroshima: ${ }^{2}$ Hiroshima University: ${ }^{3}$ Iwate University)

Paenibacillus strains are Gram-positive bacteria and found in a variety of environmental niches such as soil, foods, tree roots and insect larvae. Paenibacillus alvei AUG6 strain, used in this study, was isolated from the oral cavity of a healthy dog. Ordinary motile bacteria generally formed a swarm ring on semisolid $(0.5 \%)$ agar plates and tight colonies on hard $(1.5 \%)$ agar plates. On the other hand, $P$, alvei AUG6 strain, on the hard agar plates, formed interspersed punctiform colonies which are collectively called the nebula morphotype. By electron microscopy, we found a specialized spiral structure associated with the hook portion of the flagella.

In order to elucidate the structure and function of the spiral structures, we attempted to purify flagella that retain the spiral structures and observed them under the electron microscope. The spiral structures were attached with more than $70 \%$ of the flagellar hooks. The average number of helical turns of the spiral was 5 , and the pitch was $12.8 \pm 1.6 \mathrm{~nm}$, and the helical diameter was $28.4 \pm 1.6 \mathrm{~nm}$. The hook length was $63.6 \pm 6.1 \mathrm{~nm}$. Thus, the spiral structure may cover the whole length of the hook $(5 \times 13=65)$. We also found in the preparation spiral structures that are much longer than those attached to the hook. The number of helical turns of those structures was multiples of five, suggesting that spiral structures dropped off from flagella were polymerized through their ends. We will be discussing the function of the spiral structure in swarming.

\section{$1 P 207$ 細菌べん毛特異的蛋白質輸送に関わる FliH-FliI 複合体の X 線 結晶構造解析}

X-ray crystallographic study of the FliH-FliI complex responsible for bacterial flagellar protein export

yumiko uchida ${ }^{1}$, Tohru Minamino ${ }^{1,2}$, Keiichi Namba ${ }^{1}$, Katsumi Imada ${ }^{1},\left({ }^{1}\right.$ Graduate School of Frontier Biosciences, Osaka University: ${ }^{2}$ PRESTO, JST)

The bacterial flagellum acts as a rotary nanomachine, which consists of three parts: the basal body, the hook and the filament. Most of the flagellar proteins are translocated into the central channel of the growing flagellum by the flagellar protein export apparatus.

FliH is a cytoplasmic component of the export apparatus. FliH exists as a homodimer and forms a heterotrimeric complex with FliI ATPase, whose entire structure is similar to the $\alpha$ and $\beta$ subunits of $\mathrm{F}_{O} \mathrm{~F}_{1}$-ATPsynthase. The extreme 
$\mathrm{N}$-terminal region of FliH is responsible not only for the interaction with a flagellar C-ring protein, FliN, but also for stable association of the FliI hexamer with its docking platform the export gate made of six integral membrane proteins of the export apparatus. The C-terminal region of FliH is required for the interaction with FliI. Interestingly, the $\mathrm{N}$-terminal and $\mathrm{C}$-terminal regions of $\mathrm{FliH}$ are homologous to the $\mathrm{b}$ and $\delta$ subunits of $\mathrm{F}_{O} \mathrm{~F}_{1}$-ATPsynthase, respectively. Since the $\mathrm{b}$ and $\delta$ subunits form the peripheral stalk essential for connecting $\mathrm{F}_{1}$ with $\mathrm{F}_{O}$, these similarities suggest that FliH may act as a stalk to anchor the FliI hexamer to the export gate.

In this study, to clarify the role of FliH in flagellar protein export at the atomic level, we co-purified the $\mathrm{FliH}_{C 2}$ fragment, which consists of residues 99-235, with FliI and crystallized the $\mathrm{FliH}_{\mathrm{C} 2}$-FliI complex. Single crystals obtained by the hanging-drop vapor-diffusion technique diffracted to $2.8 \AA$ resolution. Structural analysis is now in progress.

\section{$1 \mathrm{P208}$ バクテリアベん毛特異的分子シャペロン FlgN の構造と機能解 析}

Structural and functional analyses of FlgN, a bacterial flagelIar substrate-specific export chaperone

Miki Kinoshita ${ }^{1}$, Tohru Minamino ${ }^{1,2}$, Katsumi Imada ${ }^{1}$, Keiichi Namba ${ }^{1},\left({ }^{1}\right.$ Graduate School of Frontier Biosciences, Osaka University: ${ }^{2}$ PRESTO, JST)

The bacterial flagellum is a locomotive organelle that propels the cell body in liquid environments. The flagellum is a supramolecular complex consisting of at least three parts: the basal body, the hook and the filament. Most of the flagellar proteins are translocated into the central channel of the growing structure and then to the distal end of the structure for self-assembly by the flagellar protein export apparatus, which consists of six integral membrane proteins, FlhA, FlhB, FliO, FliP, FliQ and FliR, and three cytoplasmic proteins, FliH, FliI and FliJ. In addition to these components, three flagellar proteins, FlgN, FliS, and FliT, act as substrate-specific chaperones to facilitate the export of their cognate substrates.

Since FlgN binds to the extreme C-terminal regions of the hook-filament junction proteins, FlgK and FlgL, and prevents their premature aggregation in the cytoplasm, it is thought to be a chaperone specific for FlgK and FlgL. It has been shown that FlgN also binds to export components, FliI and FliJ. However, it remains unknown how FlgN switches its binding partners during the export process.

Salmonella FlgN is a 140 amino-acid-residue protein with a molecular weight of $16.5 \mathrm{kDa}$. In this study, we expressed, purified and crystallized its Cterminally-truncated variant, $\mathrm{FlgN}(2-120)$, missing the last 20 residues. We also carried out functional analysis of FlgN. We will discuss the regulatory mechanisms of FlgN interactions with its binding partners.

\section{$1 \mathrm{P209}$ ホルムアルデヒド架橋によるナトリウムイオン駆動型ベん毛 モーターのC リング·固定子タンパク質相互作用解析 \\ Interaction analysis of C-ring and stator proteins using formaldehyde cross-linking in $\mathrm{Na}^{+}$-driven flagellar motor \\ Masafumi Koike, Seiji Kojima, Michio Homma, (Graduate School of Science, Nagoya Univ.)}

The flagellum is one of the biggest architecture in the bacterial organ. At the base of each flagellum, the ion-driven rotary motor is embedded in the membrane. Escherichia coli and Salmonella have $\mathrm{H}^{+}$-driven motor, and Vibrio alginolyticus has $\mathrm{Na}^{+}$-driven type. The flagellar motor is composed of basal body, C-ring and stator. Basal body is the rotor part of the motor. Vibrio basal body has unique ring structures important for the function named Tand $\mathrm{H}$-ring detected in our laboratory. C-ring composed of FliG, FliM and FliN, is mounted on the cytoplasmic side of the basal body, and essential for torque generation by associate with stator. FliG participates most directly in the torque generation among them. Since, however, C-ring structure has isolated just only from Salmonella, the C-ring structure of $\mathrm{Na}^{+}$-driven flagellar motor is still unknown. Previously, we isolated the basal body associate with FliG from the $\mathrm{Na}^{+}$-driven polar flagellum of $V$. alginolyticus using CHAPS. However, FliM and FliN dissociated during the C-ring preparation. Recent fluorescent analyses show the turnover of FliM and FliN in E. coli cells. In the case of Vibrio flagellar motor, stability and pattern of protein interactions in the C-ring may be different from $\mathrm{H}^{+}$-driven motor of Salmonella and $E$. coli. Currently, we tried to detect the interactions of C-ring proteins and to isolate the whole C-ring and stator complex by cross-linking experiments using formaldehyde.

\section{$1 P 210$ 基質牽引力に由来するアメーバ運動の極性形成機構}

Traction forces and directional migrations of Dictyostelium amoebas

Yoshiaki Iwadate ${ }^{1,2}$, Chika Okimura ${ }^{1,2}$, Katsuya Sato ${ }^{3}$, Kazuyuki Minami ${ }^{4},\left({ }^{1}\right.$ Graduate School of Medicine, Yamaguchi University: ${ }^{2}$ PRESTO, JST: ${ }^{3}$ Institute of Technology and Science, Graduate
Schoot, The University of Tokushima: ${ }^{4}$ Graduate School of Science and Engineering, Yamaguchi University)

Living cells are constantly subjected to various mechanical stimulations. They must sense the mechanical aspects of their environment and respond appropriately for proper cell function. In general, cells adhere to substrata. Thus, the cells must receive mechanical stimuli mainly from the substrata and respond to them.

For example, migrating cells can create their own polarity and migrate in a certain direction even in the absence of any chemoattractant. In order to generate such polarity, cells must sense mechanical stimuli from the substrata and transduce them into intracellular signals.

To investigate the relationship between signals derived from mechanical stimuli and cell polarity;

(1) we visualized the traction forces of a migrating Dictyostelium cell,

(2) observed the cell migrations on an elastic substrata with different hardnesses in directions, and

(3) applied mechanical stimuli to the cells via cyclic stretch of elastic substrata and observed the migrating directions of the cells and localization of molecules related to the cell migration.

We will discuss the relationship between the traction forces and the directional cell migration.

\section{$1 \mathrm{P} 211$ 微細直進経路内の粘菌アメーバの運動}

Directional migration of Dictyostelium amoebas in a narrow straight tunnel

Chika Okimura ${ }^{1,2}$, Yuichi Hiratsuka ${ }^{3}$, Yoshiaki Iwadate ${ }^{1,2},\left({ }^{1}\right.$ Graduate School of Medicine, Yamaguchi University: ${ }^{2}$ PRESTO, JST: ${ }^{3}$ School of Material Science, Japan Advanced Institute of Science and Technology)

It is generally believed that the mechanism of cell migration is based on actin polymerization at the front of the migrating cells, and actomyosin-dependent contraction at the rear. However, cells change their migrating direction very frequently. The portion, which was anterior of a migrating cell, becomes posterior at the next moment. Thus, it is very difficult to observe the dynamics of actin at the front and actomyosin at the rear constantly. To clarify the detailed relationship between cell migration and the molecular dynamics, it is desirable to observe constant straight cell migrations without directional change.

To realize the constant directional cell migration and the observation of the dynamics of molecules such as actin and myosin II under the situation, we applied Dictyostelium cells in a narrow straight tunnel under a gradient of concentration of the chemoattractant, cAMP. The cells migrated straight to the side of the high concentration of the cAMP. We observed the molecular dynamics in the cells migrating in the narrow tunnel and will discuss the mechanism of the directional cell migration.

\section{$1 \mathrm{P} 212$ ストレスファイバーにおける極性の周期構造形成 $1 \mathrm{C1255}$ Polarity patterns of stress fibers}

Natsuhiko Yoshinaga ${ }^{1}$, Philippe Marcq ${ }^{2,3},\left({ }^{1}\right.$ Fukui Institute for Fundamental Chemistry, Kyoto University: ${ }^{2}$ Physico-Chimie Curie, Institut Curie: ${ }^{3}$ Universite Pierre et Marie Curie)

Stress fibers are contractile actomyosin bundles commonly observed in the cytoskeleton of metazoan cells. The spatial profile of the polarity of actin filaments inside contractile actomyosin bundles is either monotonic (graded) or periodic (alternating). In the framework of linear irreversible thermodynamics, we write the constitutive equations for a polar, active, elastic one-dimensional medium. An analysis of the resulting equations for the dynamics of polarity shows that the transition from graded to alternating polarity patterns is a nonequilibrium Lifshitz point. Active contractility is a necessary condition for the emergence of sarcomeric, alternating polarity patterns.

\section{$1 \mathrm{P213}$ 織毛の新機能 : シグナル伝達増強作用}

A new function of cilia, cell-signaling enhancer, revealed by the simulation analysis of intra-ciliary diffusion

Daisuke Takao ${ }^{1,2}$, Shinji Kamimura ${ }^{3},\left({ }^{1}\right.$ Department of Life Sciences, Graduate School of Arts and Sciences, The University of Tokyo, Tokyo, Japan: ${ }^{2}$ Laboratory for Spatiotemporal Regulations. National Institute for Basic Biology, Aichi, Japan: ${ }^{3}$ Department of Biological Sciences, Faculty of Science and Engineering, Chuo University, Tokyo, Japan

Along with the well-known function of propelling fluid flows in a surrounding medium, eukaryotic cilia support other fundamental roles of sensory receptors as known from morphological descriptions as well as from recent evidence on the functions of primary cilia. However, we have yet to find any definitive answers to a basic question, namely, why the ciliary structure is frequently 